\title{
Governance for excellence and diversity? The impact of central and regional affiliation for the strategic positioning of Chinese top universities
}

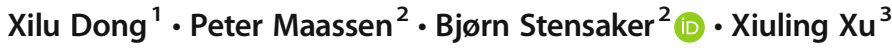

Published online: 22 February 2020

(C) The Author(s) 2020

\begin{abstract}
Through analysis of the strategic ambitions of China's top universities, this article studies the relationship between governance structures at the system level and strategic institutional adaptations. In China, some top universities are governed directly by the national authorities while others have regional affiliations. By analyzing the strategic plans of a sample of universities in both categories the article examines how these differences in governance modes may impact the formal ambitions and objectives of the universities and discuss the potential system implications of these different governance modes, especially related to issues of excellence and diversity. The article find that differences in governance modes do affect the strategic positioning of Chinese universities, and different ways in which governance arrangements can be used to foster both excellence and diversity in a system perspective are discussed.
\end{abstract}

Keywords World-class universities · Governance - Excellence - Institutional strategy Institutional diversity

\section{Introduction}

The functioning of higher education systems with respect to balancing excellence and diversity is a highly discussed topic internationally (Frank and Cook 1996; Marginson

Electronic supplementary material The online version of this article (https://doi.org/10.1007/s10734-02000516-3) contains supplementary material, which is available to authorized users.

Bjørn Stensaker

bjorn.stensaker@iped.uio.no

1 Institute of Education Sciences, Wuhan University, Wuhan 430072, China

2 Department of Education, University of Oslo, 0317 Oslo, Norway

3 Graduate School of Translation and Interpretation, Beijing Foreign Studies University,

Beijing 100089, China 
2011). Driven by globalization and the emergence of global university rankings, it is possible to argue that excellence has become a key item on the university policy agenda in many countries (Hazelkorn 2015), often with subsequent worries that system diversity might suffer as all major institutions are forced to adapt strategically to the excellence agenda (Douglass 2010).

This issue is also relevant in China. The Chinese higher education system is vast and diverse including both public and private colleges and universities. The total number of institutions of higher learning in the country is fast approaching 3000 of which more than $30 \%$ are private institutions. Most of the growth has still taken place in the public sector, and more than 2000 colleges and universities have been established by regional and local authorities in the country during the last decades (Bie 2015). The emphasis on the growth of the system does not mean that issues of excellence are absent from the policy agenda. Public authorities in China have during the last decades launched several policy initiatives to foster a smaller number of so-called world-class universities characterized by excellence especially with respect to research (Zhou and Peng 2008). In the latest version of these policy initiatives, the Chinese national government is committed to building world-class universities and first-class disciplines since 2015, and the "Double First Rate" policy has rapidly become the policy buzzword in Chinese higher education (Bie 2015; Dong et al. 2019).

In China, most of the selected excellent universities are affiliated directly with the central Chinese government. However, the aim of developing excellent universities opens up interesting questions related to how such commitment from the national public authorities influences how universities affiliated to regional and local authorities are positioning themselves within the Chinese higher education landscape. In many countries where the higher education system has been affected by an excellence agenda and the striving for world class status, a trend towards academic drift can be observed (Kyvik 2009; Kehm and Stensaker 2009; Altbach and Salmi 2011; Pusser and Marginson 2013). Assuming that the ability to balance excellence and diversity is crucial for system effectiveness in higher education (van Vught and Westerheijden 2012), a challenge is to analyze how such a balance may be achieved. In the efforts to create such a balance, system level governance can be expected to play a key role, especially when it comes to the possible impacts of various governmental policy initiatives (Ramirez and Christensen 2013). The current article has the ambition to contribute to the discussions about the relationship between university excellence and system diversity by addressing the following research question: How is system level governance affiliation influencing the weight given to excellence and diversity in the strategies of Chinese major universities?

The article is organized as follows. First, an overview of relevant policy and empirical developments the last couple of decades in Chinese higher education is provided. Based on this overview, a theoretical framework is outlined where two perspectives - an instrumental and an institutional-are presented as ideal-type heuristics for understanding the relationship between governance arrangements and university adaptations at a strategic level. The empirical section contains an in-depth analysis of the strategic plans of a sample of major universities in China, some of which are centrally governed, and some are governed by regional/local authorities. In the concluding section, the findings are discussed, and implications are outlined with respect to the relationship between system level governance and the ambitions of building a balance between excellence and diversity in higher education systems. 


\section{Growth, diversity, excellence and governance in Chinese higher education}

In China, national authorities have played an important role in pursuing higher education excellence and diversity (Benner et al. 2012). Over the past 20 years, Chinese higher education has been transformed from being a relatively small elite system into one of the largest higher education systems in the world. In 2016, there were 2596 higher education institutions in China (National Bureau of Statistics of China 2017). After 1948, the development of Chinese higher education found inspiration in the Soviet model, with institutions affiliated with different ministries reflecting the diversified missions and purposes of the universities and colleges. At system level, this resulted in a two-tier system where the most prestigious central institutions were affiliated with different ministries, while the others came under regional/local jurisdiction. However, as the higher education system started to expand in the late 1990s, a reorganization took place transferring some of the earlier centrally affiliated institutions to regional/local ownership. A parallel establishment of new higher education institutions at regional/local level, together with an upgrading of existing vocational institutions further reinforced the existing two-tier system (Hu 2017).

Since the late 1990s, the objective of developing excellent universities also became more prominent in the national policy agenda (Zhou and Peng 2008; Zheng and Cheng 2012; Hu 2017). It is worth noting that almost all higher education institutions that were selected with the purpose of becoming "excellent were under the direct control of central ministries. As a consequence, they were largely out of direct control of local governments. Currently, 116 higher education institutions are under the direct jurisdiction of the national government. Among them, a total of 76 are affiliated to the Ministry of Education (MOE), while the rest is affiliated to other ministries. In general, institutions affiliated with the national government have higher prestige and have considerably more financial resources than those under regional/ local jurisdiction (Ying et al. 2017).

In terms of public governance, all universities - regardless of affiliation - are required to have a Party Secretary in their central leadership structure. The appointments to this position along with those to the position as University President are controlled by central or regional/ local authorities. With respect to fiscal appropriations, universities affiliated with the central authorities are funded from Beijing, while regional/local authorities are the main funders of their own institutions.

Hence, Chinese higher education has over time formed the two-level governance model with national government responsible for some institutions, while regional/local governments are responsible for others. This governance design allows for some political autonomy not least to serve the regional/local economy, market or culture, although it is expected that regional/local governments are operating within the frames and conditions set by the national public authorities. Nonetheless, the freedom to set up their own higher education institutions has been utilized by the regional/local authorities, and in general, it is here the recent growth in the number of higher education institutions can be found.

One of the dilemmas that can be identified in this two-tier form of governing higher education is that both central and regional/local authorities are interested in promoting highquality education and research, but that the higher education system in China has many objectives and aims it should fulfill (Benner et al. 2012). It is also interesting to notice that several regional/local governments have selected a number of key universities in their own province or city, which they want to promote regarding status and academic quality (Luo 2008, 
30-33). However, as not all regional/local governments have the same financial resources as the central government, the financial room to maneuver is considerable larger for the institutions affiliated directly with Beijing (Ying et al. 2017).

In general, one could argue that the governance of higher education in China has been designed to cater for both excellence and diversity. While the centrally funded universities, in general, are stimulated to aim for excellence and for reaching world-class status, the regionally/ locally affiliated universities are expected to cater for the needs and expectations of particular regions. The fact that the Beijing affiliated universities have both more economic resources and higher academic status may still imply a situation where some regionally/locally embedded universities have the desire to change their affiliation and status. What kind of balance between excellence and diversity the higher education governance arrangements in China may uphold is therefore an issue of scholarly interest as well as of relevance to all national authorities that have introduced policy programs for promoting university excellence.

\section{Theoretical perspectives on governance for excellence and diversity}

\section{Research on and trends in the governance of higher education}

The ongoing globalization of higher education has influenced the domestic policy agendas in many countries around the world, including China (Morris 2011; Bie 2015). An important mechanism associated with globalization is the rise and influence of university rankings. These rankings have in a number of respects been an important driver of discussions on how excellence can be stimulated and how to obtain the status of being a "world-class" university (Kehm and Stensaker 2009). As rankings have proliferated, there are a number of studies demonstrating how such measures affect national higher education systems and institutions (Kehm and Stensaker 2009; Morris 2011; van Vught and Westerheijden 2012; Pusser and Marginson 2013; Hazelkorn 2015; Ying et al. 2017).

However, in most countries, issues related to excellence are not the only concern influencing higher education policies as issues related to developing a higher education system that can cater for the diverse needs and demands that exist domestically also tend to be high on the policy agenda (Maassen 2012; van Vught and Westerheijden 2012). Higher education has many different and often contradictory functions - economically, politically, socially, and culturally - that any higher education system is expected to encompass (Castells 2001). While excellence and diversity are not necessarily contradictory dimensions, there are a number of voices being quite skeptical as to how they are balanced in an increasingly globalized sector (Douglass 2010).

The specific national governance arrangements with respect to higher education determine the main framework conditions under which national governments can influence how excellence and diversity can be achieved. There is, nevertheless, little agreement on which governance approach is most effective in achieving an optimal balance among excellence and diversity. For some, de-regulation and the introduction of market-like mechanisms are seen as the best approach (Salmi 2009). In this perspective, effective governance implies that governments steer less and allow for more autonomous institutions having the capacity to make organizational strategic choices on their own and finding niches that - in a system perspective - cater for both excellence and diversity. This perspective has inspired many reform attempts internationally, resulting in hybrid steering approaches of the higher education with a myriad of agencies and stakeholders (Gornitzka and Maassen 2000). For the 
institutions, this trend is argued to have resulted in the creation of a strengthened steering core of many universities (Clark 1998), implying more centralized and formalized institutions (Ramirez and Christensen 2013). It has also been claimed that higher education institutions in general have developed some "generic" features and have become more organized actors capable of both developing and implementing independent strategies and profiles in the emerging higher education market. However, there are also a number of more critical studies suggesting that governance designs where governments step back result in institutional strategies that prioritize status and reputation over service to society and the public good (Marginson 2011; Morris 2011). Overall, there seems to be an unclear relationship between governmental reform agendas inspired by competitive market ideologies and the change dynamics in universities and colleges. This situation has been referred to as representing a "governance paradox" (Maassen 2017).

Those being skeptical to the belief that a stronger market-orientation will solve the excellence - diversity dilemma tend to argue for governance designs where the government is far more active in governing the higher system (Kyvik 2009; Maassen et al. 2011). Such designs may include the use of institution-specific strategic agreements between the government and each individual institution (Gornitzka and Larsen 2004), and the setup of sectoral public agencies with the mandate to implement specific policy agendas domestically, or regulatory frameworks restricting academic drift (Maassen and Stensaker 2011). At the same time, a number of scholars suggest that such governance designs may have side-effects that influence the effectiveness of the higher education institutions (Ramirez and Christensen 2013), and that pro-active governmental steering may not represent a guarantee against academic and reputational drift (Kyvik 2009; Tuchman 2009).

\section{An instrumental and an institutional perspective on university governance}

The research on the impact of various governance arrangements suggests that formal structures and regulations may play a role securing excellence and diversity, but that also such structuresespecially over time - may be infused with and affected by external influences, not least stemming from the ongoing globalization (Djelic and Sahlin-Andersson 2006; Hazelkorn 2015). To shed light on how system developments unfold in a situation where traditional governance structures may be exposed to powerful global reform ideas (Gornitzka and Maassen 2014; Yudkevich et al. 2016), two perspectives are especially relevant. First, an instrumental perspective is focusing on how universities can be governed most efficiently for achieving their (externally) determined tasks and objectives. Second, an institutional perspective paying more attention to how global cultural ideas penetrate public sector governance, and restricting and perhaps even counter-acting the influence of established control and command lines (Olsen 2007, 26-27).

The instrumental perspective emphasizes the importance of formal structures and reform agendas and that the state is still the key principal in higher education (Capano 2011). Strategic plans are in this perspective one of the key tools for governmental steering as they are part of an integrated system of regulations and rules, through the design of national funding systems, and through the influence over formal organizational issues (Capano 2011). While regional and local authorities may have some autonomy, an instrumental perspective underlines that such autonomy is delegated and strictly controlled through various accountability schemes securing the central state control over key decisions in the system (Olsen 2007; Howlett 2013). More formal autonomy provided to decision-making levels at lower levels in the system does not necessarily imply more real autonomy (Christensen 2011). 
An institutional perspective acknowledges that powerful ideas, constitutive rules and practices, and taken-for-granted assumptions shape national authorities, institutional leadership and academics, making formal structures less important as mechanisms of steering, transforming both principals and agents perceptions about what to do, and how to do it (Djelic and Sahlin-Andersson 2006). This perspective emphasizes the robustness of the university that is embedded in continuous importance of a basic set of rules and organized practices, relatively independent of changing internal and external circumstances, including which individuals possess leadership positions and which government is in charge. As argued by Olsen (2007, 27; see also March and Olsen 1989), among other things, the structure and level of institutional funding is highly relevant, since "Structures of resources create capabilities for acting; they empower and constrain actors differently and make them more or less capable of acting according to prescriptive rules."

The institutional robustness of universities on the one side and internationally dominant reform templates on the other create situations where state coordination becomes very difficult due to the existence of many competing ideas and priorities (Maassen and Stensaker 2011; Gornitzka and Maassen 2014). Strategic plans are in this perspective a more symbolic tool, nevertheless important as they may maintain and strengthen the legitimacy of the university towards external stakeholders (Ramirez and Christensen 2013). However, in a situation where there is much uncertainty about what to do, an institutional perspective predicts that many organizations will imitate those that are perceived as being most successful (Riesman 1958; DiMaggio and Powell 1983; Stensaker et al. 2018). This implies that many universities and colleges would try to imitate those research universities with the highest national, if not global status.

\section{Governance affiliations in China: key expectations}

Using the two perspectives outlined as points of departure for the analysis of the excellence policies' impact on Chinese universities, expectations related to an instrumental perspective would imply that those institutions that are controlled directly by the national government, and that are also selected to become excellent institutions, would develop strategies and institutional profiles that strongly reflect this priority. Those institutions that are affiliated with regional and local authorities would conversely develop strategic plans that contain other priorities, even if these institutions potentially may possess the capacity for becoming excellent, world-class universities.

From an institutional perspective the expectations are that a large group of institutions regardless of whether they are steered directly from the national government or having regional or local affiliations would develop strategies and institutional profiles that emphasize excellence. For the regional and local institutions, the expectation is that they would mimic the strategies of those universities formally selected by the central authorities as candidates of becoming world-class, more so if they enjoy some prestige and have the financial muscles to do so.

\section{Data and methods}

\section{Empirical design}

China's higher education institutions come in many forms. Although the main task of constructing world-class universities and first-class disciplines is resting on comprehensive 
research-intensive universities' shoulders (Dong et al. 2019), there are many other types of universities and colleges within the system as well, including normal universities, agricultural universities, forestry universities, universities of medicine, private institutions, etc. While these institutions may represent a more narrowly disciplinary or institutional profile, some of them are also selected as potential world-class candidates and have therefore been included in the sample of universities covered in this article.

Thirty higher education institutions have been selected for the analysis representing the central and regional/local governance arrangements respectively. Four criteria have guided the sample selection: (1) Centrally governed institutions and regionally/locally governed institutions should be of a similar type. (2) Furthermore, the selection of institutions has taken into account the fact that the eastern and central regions in China are more developed than others, having the consequence that the number of "excellent" institutions are mostly located in Beijing, Shanghai, Jiangsu, Hubei, and Shaanxi regions, making them the five most powerful provincial administrative regions in higher education. To avoid too much geographical skewness, the inclusion of institutions from other provincial administrative regions in our sample has been prioritized as much as possible. (3) As excellence policies have been launched in different phases (Dong et al. 2019), the sample contains institutions selected in all the stages making the excellence group as diverse as possible. (4) The sample has also taken into account the financial resources of the institutions and the prestige they enjoy, measured by their position in the ranking of China's best universities (see below).

Key data and indicators attached to the sample are shown in Appendix 1. The appendix is based on official data and public available information, including the ranking (2018) of China's Best Universities (Shanghai Ranking). The budget data are from the 2018 budget provided by the official websites of each university. A few local universities did not display budget data.

In general, the appendix shows huge differences between centrally and regionally/locally affiliated institutions. These differences reflect historical trajectories, such as the inclusion of the institution in previous excellence initiatives. In the sample of centrally affiliated institutions, all institutions have budgets exceeding 2 billion CNY, and all of them are ranked within the top 100 institutions in the country. In the sample of regional/locally affiliated institutions, only two institutions have budgets exceeding 2 billion CNY, and all-except for two institutions - have a ranking position between 100 and 500. However, the diversity found within the sample is worth noticing, not least the huge difference in financial capability between the top-ranked institutions (Tsinghua, Fudan and Sun Yat-Sen) and those that are lower ranked (e.g., Northeast Normal University and Heifei University of Technology). Also within the sample of regional/locally affiliated institutions there is considerably diversity. Shanghai and Nancheng universities have budgets that compare with some of institutions that are centrally affiliated, and some have ranking positions that are quite high, although their budgets are not comparable to the most prestigious institutions (e.g., Tianjin University).

\section{Data analysis}

As all Chinese higher education institutions are required to develop and implement 5-year plans, we have taken these plans as the main data sources based on the assumption that these plans reflect the main institutional objectives, strategic ambitions and ways to accomplish them.

The 5-year plans of the selected institutions have been divided into two groups containing 15 documents each, which have been quantitatively and qualitatively analyzed. Quantitatively, the 
documents' texts have been analyzed with the aid of a text corpus tool labeled BFSU PowerConc - a free software developed by the Corpus Research Group at Beijing Foreign Studies University. This software searches words and phrases, and produces lists of words and word clusters, that is, multi-word units or combinations of words, in a text. Moreover, the software can compare the lists of clusters in two texts to generate a list of clusters that occur statistically significantly more frequently in one text than in another-a list of key clusters (Baker 2006, 140). Usually log-likelihood (LL) tests are used to compare two lists of clusters in order to derive key clusters. If the LL value is greater than 3.84 , there is statistically significant heterogeneity between the frequencies of the cluster in question in the two texts. In general, the larger the LL value, the stronger the dissimilarity. Key clusters can be calculated automatically using the "keyness" function in BFSU PowerConc. The key clusters in each group of texts were generated to compare the strategies of universities in the two governance arrangements.

The 15 texts collected in each group are called here a "corpus" in linguistic terms, with "Central Corpus" referring to the universities governed directly by the central authorities, and "Regional/Local Corpus" referring to the institutions governed by regional/local authorities. A list of key clusters in the "Central Corpus" was generated by comparing the frequencies of the clusters in the "Central Corpus" with those in the "Regional/Local Corpus", as the reference corpus. Similarly, a list of key clusters in the "Regional/Local Corpus" was generated by comparing the frequencies of the clusters in the "Regional/Local Corpus" with those in the "Central Corpus," as the reference corpus. After initial analysis, the two lists of key clusters were cleaned by eliminating the clusters that were considered as irrelevant or not containing valid information. We also checked for overlapping of key clusters, such as "with world-class university," "world-class university and," "world-class university's," and "build world-class university," manually assessing in what context these phrases occurred. Since the 5-year plans were written in Chinese, all relevant phrases were translated into English.

\section{Results}

The results after filtering are shown in Appendices 2 and 3, with "Fre." referring to the frequency of one key cluster in a specific corpus. "World-class," for example, is mentioned 324 times in the central corpus. "Ref-Fre." means that the same key cluster appears only 31 times in the regional/local corpus. The features of diversified key clusters were grouped into six categories: positioning, discipline, talent, service, governance, and party building.

To further data mining, the function of "Collocates" is used. This function effectively reflects the collocation of phrases of specific key clusters in the text, thus helping to deeply understand those strategic plans' features. Specifically, we selected key clusters with a "Fre." value of more than 20 (Appendices 2 and 3), and carried out collocation of phrases retrieval. The results are presented in Tables 1 and 2, respectively.

\section{Positioning}

Key clusters of "world class" and "world-class university" have an extremely high L value that in both cases is greater than 100. It shows the strong desire of the centrally selected universities to build their excellent, world-class university status, and it also shows that this type of university actively takes up its determination and sense of responsibility, as well as the underlying strength in the Chinese efforts to enhance its influence on higher education at the 
Table 1 Categorized collocates of main key clusters in central corpus

\begin{tabular}{|c|c|c|}
\hline Categories & Key clusters & Examples of collocates \\
\hline \multirow[t]{4}{*}{ Positioning } & World-class & $\begin{array}{l}\text { University, discipline, Chinese characteristics, procession, level, } \\
\text { build, imitate, lessen }\end{array}$ \\
\hline & World-class university & $\begin{array}{l}\text { Chinese characteristics, strengthen, first-class disciplines, level, } \\
\text { procession, gaps, cooperate }\end{array}$ \\
\hline & $\begin{array}{l}\text { International cutting-edge re- } \\
\text { search }\end{array}$ & Active in, aim, face, national major, national innovation \\
\hline & Chinese characteristics & $\begin{array}{l}\text { Deepen, uphold, philosophy and the social sciences, new types of } \\
\text { think tanks, modern university institutions, world-class } \\
\text { university, socialism }\end{array}$ \\
\hline \multirow[t]{4}{*}{ Disciplines } & World-class discipline & Enter into, a batch, forefront, procession \\
\hline & Fundamental research & Emphasis, apply, leading edge, improve, ability, level, teacher \\
\hline & Disciplinary ranking & Domestic, global, first-level, key, top $1 \%$, enter into \\
\hline & Preponderant disciplines & Tradition, characteristic, strike, world-class, lead role \\
\hline \multirow[t]{2}{*}{ Talents } & Entrepreneurship education & $\begin{array}{l}\text { Innovation, platform, reform, integration of talent cultivation, } \\
\text { curriculum system }\end{array}$ \\
\hline & $\begin{array}{l}\text { Strengthen moral education } \\
\text { and cultivate people }\end{array}$ & Center on, implement, persist, basic task \\
\hline Service & National key & Focus, serve, satisfy, strategy, demand, research, project \\
\hline Governance & Logistical support & Quality, improve, resources, supervise, manage \\
\hline \multirow[t]{2}{*}{$\begin{array}{l}\text { Party } \\
\text { building }\end{array}$} & Core socialist values & $\begin{array}{l}\text { Develop and expand, strengthen, persist, practice, integrate, } \\
\text { education, propaganda, leading }\end{array}$ \\
\hline & $\begin{array}{l}\text { Ideological and political } \\
\text { theory course }\end{array}$ & $\begin{array}{l}\text { Give play to, strengthen, deepen, rely on, teaching, teacher, main } \\
\text { channel }\end{array}$ \\
\hline
\end{tabular}

Table 2 Categorized collocates of main key clusters in regional/local corpus

\begin{tabular}{|c|c|c|}
\hline Categories & Key clusters & Examples of collocates \\
\hline \multirow[t]{3}{*}{ Positioning } & Domestically well-known & High-level, distinctive features, university \\
\hline & High-level university & $\begin{array}{l}\text { Construction, characteristic, China Scholarship Council, overseas, } \\
\text { cooperation, joint training, academic training }\end{array}$ \\
\hline & First-class in China & Construction, a batch, attain, university, discipline \\
\hline \multirow[t]{2}{*}{ Disciplines } & Characteristic discipline & Provincial, superior, subject specialty group, potential \\
\hline & Key discipline & $\begin{array}{l}\text { National, provincial, characteristic, advantage, newly increased, } \\
\text { rely on }\end{array}$ \\
\hline \multirow{5}{*}{ Talents } & International exchange & Student, cooperation, platform \\
\hline & High-level & Bring in, national, overseas, provincial, youth, talent \\
\hline & Leading talent & Technology, youth, discipline, lack, expansion plan \\
\hline & Academic leader & $\begin{array}{l}\text { Chief professor, provincial, outstanding young and middle-aged } \\
\text { intellectuals, senior professor, core }\end{array}$ \\
\hline & Backbone teacher & $\begin{array}{l}\text { Youth, discipline, bring in, overseas training, international } \\
\text { cooperation training }\end{array}$ \\
\hline \multirow[t]{2}{*}{ Service } & $\begin{array}{l}\text { Transformation of scientific } \\
\text { research achievements }\end{array}$ & Improve, ability, platform \\
\hline & Pairing assistance project & $\begin{array}{l}\text { Rely on, Tsinghua university, West China, advantage, university, } \\
\text { support }\end{array}$ \\
\hline \multirow[t]{4}{*}{ Governance } & Coordinated development & $\begin{array}{l}\text { Beijing-Tianjin-Hebei, Yangtze River Economic Belt, regional } \\
\text { characteristic, think tank, talent team, external cooperation }\end{array}$ \\
\hline & Key project & $\begin{array}{l}\text { National, National Natural Science Foundation, National Social } \\
\text { Science Foundation }\end{array}$ \\
\hline & Key laboratory & National, MOE, provincial, zero breakthrough \\
\hline & $\begin{array}{l}\text { Cooperation in running } \\
\text { universities }\end{array}$ & International, sino-foreign, advance, new pattern, project \\
\hline
\end{tabular}


world stage. Although the centrally selected universities have to face a global competitive environment, they also refer to the establishment of philosophy and social sciences, first-class university as well as socialism with "Chinese characteristics." To some extent, this is inseparable from party building, which will be covered below. Differently, for regional/local universities, their development goals are mainly to become "domestically well-known," "first-class in China," and "high-level university." In China's higher education system, universities first have to become "high level" which is the prerequisite for moving forward to "world-class" status. These regional/local institutions focus mainly on the domestic higher education market, as illustrated below:

It provides a rare opportunity for us to explore the construction and development of high-level universities with 'national first-class, regional leading, central China style' (Henan University).

\section{Discipline}

In general, centrally affiliated universities are more internationally oriented than regional/local universities. Although both types of institutions refer the importance of developing quality, the regional/local institutions pay more attention to the domestic market. The adjective of "characteristic" is mentioned with high frequency in the regional/local corpus, but refers mainly to discipline development instead of the institution as a whole:

...put emphasis on the construction of metallurgical engineering, material science and engineering, mining and so on, and focus on building national first-class disciplines (Wuhan University of Science and Technology).

\section{Talent}

Centrally affiliated universities emphasize their talent pool, which is different from the talent cultivation of regional/local universities. Because central universities already have a huge pool of talent, they seem to focus on how to further develop the productivity and careers of talents, for example, through strengthening their involvement in teamwork, as well as their involvement in international cooperation, with the aim to create more value. The analysis also displays a high frequency key cluster of "entrepreneurship education" in the central corpus, which collocates involve innovation, platform, integration of talent cultivation, etc., reflecting the strong consciousness of centrally affiliated universities to transfer knowledge into the productive forces in society. In attracting young talents, central universities also seem to have set their sights on tapping into the international academic talent pool through the "Recruitment Program of Global Young Experts." In contrast, regional/local universities attach more importance to the cultivation of young scholars, such as "Postdoctoral research," but mainly at the national level by encouraging them to apply for "National Science Fund for Distinguished Young Scholars."

\section{Service}

Central universities mainly serve the major national needs and strategies, and tend to see themselves as key in building an innovation-oriented country as exemplified by the quote from one of the involved universities from the Beijing area: 
focus on the strategic target of building a world-renowned high-level research university, adhere to the guidance of meeting national major demand. Facing the forefront of science and technology development, we should strive to improve the self-dependent innovation ability based on disciplines (Beijing University of Posts \& Telecommunications)

In the applications for national key projects, it is often easier for the centrally affiliated universities to obtain projects because of being equipped with abundant resources and adequate staff capacities. Regional/local universities tend to portray their institutions as engines of regional/provincial development where they commit themselves to serving regional socio-economic needs through the transfer of scientific research output to regionally coordinated development, such as the Coordinated Development of the Beijing-Tianjin-Hebei Region.

\section{Governance}

The strategic plans of central universities are not very specific with respect to governance, perhaps because their institutional governance structures tend to be more progressive and modern than those of regional/local universities. However, it is worth noting that the high frequency of the "logistics" cluster, collocating with quality, resources, supervision, etc., shows that an effective scientific and sound logistics system is regarded to be extremely important to the healthy development of universities. For instance, teachers' and students' accommodation is a key resource in the recruitment and admissions strategies and practices of all higher education institutions. Constrained by more limited resources, regional/local universities are more likely to adopt cooperative management approaches with other higher education institutions. Their strategic plans present more requirements on institutional management, such as improving teaching quality, promoting regional cooperation as underlined below:

We will expand the program of substantive cooperation with higher education institutions of Taiwan, and explore the new model of cooperation (Jimei University)

\section{Party building}

Party building is an indispensable part of every higher education institution in China. However, as shown in Tables 1 and 2, central universities place more emphasis on "Party building" in their strategic plans than regional/local universities, especially the "core socialist values," with a frequency of 52 are noticeable. This can be illustrated by how central universities describe their political role:

We will deepen the teaching reform of ideology and politics theory course education, strengthen and improve the ideological and political work of the faculty, carry out indepth the socialist education with Chinese characteristics, cultivate and practice core socialist values (Hunan University)

In the regional/local corpus, especially, the "Marxist youth training project" is emphasized several times, but compared to the central universities, the frequency is very moderate. 


\section{Summary}

Centrally affiliated universities, which are all among the top universities in China, tend to perceive themselves as the most important engines of the development of national innovation and at the forefront of China's higher education system. They are internationally-oriented, and their goal is to become a "world-class university" with the means of cultivating talent teamwork and building "world first-rate" disciplines. Furthermore, logistical support is viewed as a key, basic governance issue. Regional/local top universities perceive themselves as central in regional/local economic development strategies and processes, and they perceive their institutions as "role models" for other regional/local higher education institutions. Their ambitions are to become domestic first-class universities rather than imitating the central universities. The strategies of the regional/local universities focus on the need to foster proactive and pragmatic academic leaders, through strengthening selected disciplines, and through cooperation with other universities. An interesting difference between the two groups of universities is that central universities strongly incorporate "Party building" in their strategic plans, while regional/local universities seem to be somewhat less focused on this objective in their strategic planning (Table 3).

\section{Discussion and conclusions}

In this article, two analytical perspectives were applied that offer different expectations and explanations when it comes to how the efforts of centrally and regionally/locally affiliated universities in China to balance excellence and diversity are affected by the dominant governance arrangements. The instrumental perspective offered an optimistic view on the ability of the national governance arrangements with respect to higher education to maintain a distinction between the excellent centrally affiliated and the more diversified regionally/locally affiliated institutions. On the other hand, the institutional perspective assumed that some of the regionally/locally affiliated universities would be tempted to imitate the strategies and positions taken by the more funded and more reputed centrally affiliated institutions. Our findings indicate that there is a noticeable difference in the strategic plans of the two groups of universities suggesting that the current governance arrangements have the potential to balance excellence and diversity effectively at the system level.

The comparison of the strategic plans of the two groups of universities revealed that they differ in the extent they refer to world-class as a standard they need to live up to and how they want to contribute to society. In general, the regional/locally affiliated universities are not mentioning a world-class ambition and they seem to have a clear orientation towards regional

Table 3 Strategic planning features of central universities and regional/local universities

\begin{tabular}{lll}
\hline Categories & Central universities & Regional/local universities \\
\hline Positioning & World-class, Chinese characteristics & National well-known, comparative advantage \\
Discipline & World first-class & National first class \\
Talent & Teamwork & Academic leader \\
Service & National key needs & Regional economic development \\
Governance & Logistical support & Cooperation in running \\
Party building & Strong degree & Low-middle degree \\
\hline
\end{tabular}


needs and characteristics. As was expected, the universities with a central affiliation have quite different strategies reflecting to a large extent the national policy initiatives of building worldclass institutions, even if their financial muscles to realize this objective may be more limited (cf. Hefei University of Technology and Beijing University of Post \& Telecomunications).

The findings show the strong impact of an instrumental perspective in the formal governance arrangements in Chinese higher education. This is clearly visible in the institutions' 5-year plans, suggesting that formal governance arrangements matter regarding how to balance excellence and diversity in a higher education system. The fact that Chinese universities all have a party secretary within their institutional leadership structure is one explanation for this strong effect of the instrumental governance perspective. Having "the central authorities" present in the day-to-day governance of every institution could be seen as a guarantee that the political agendas created in Beijing are adhered to throughout the higher education landscape, and especially in the centrally affiliated institutions. An interesting aspect in this is that the governance arrangements seem to affect the extent to which institutions give attention to prioritized political issues, such as "party-building" activities. The institutions directly affiliated with the central authorities are strongly addressing political issues, while the regionally/locally affiliated institutions only incorporate these issues to a low-middle degree - despite the fact that they also have a party secretary in their midst. This could be interpreted as an indication that the instrumental perspective is less dominant in the regional/local than in the central governance arrangements.

The latter also hints at the relevance of an institutional perspective for interpreting the differences between the two governance arrangements when it comes to their impact on the Chinese universities' strategic ambitions. Obviously, our empirical focus on the required five-year institutional plans implies a strong emphasis on the formal governance relationships between public authorities and higher education institutions. As expected, given the nature of the Chinese political system, in these formal arrangements the instrumental perspective of the public authorities is presenting key framework conditions for the strategic ambitions of Chinese universities. These are primarily aimed at the centrally affiliated universities, on the assumption that they can be expected to contribute most to the realization of the underlying political agenda. Regional/local universities operate in a more varied governance environment where the influence of regional/local authorities provides them with more room to maneuver in determining their institutional ambitions. While our results show, for example, few signs of open world-class ambitions in the institutional plans among the regional/local universities, it should still be noted that there is a clear excellence agenda at least within the institutions that are highly ranked (Shanghai and Tianjin Medical University). For the remaining regional/local institutions, one could also argue that their aim of becoming first-class in specific disciplines is an early sign of the excellence agenda is affecting the strategic development also of these institutions. Since our data are not longitudinal, thereby restricting the possibility to study change over time, we have limited knowledge about how the strategic ambitions develop over time in these institutions and whether the intention of becoming first class is only a step on the way to grander ambitions. A typical characteristic of academic drift is that it develops over time, and is in general hard to notice in a short-time perspective (Kyvik 2009).

How do the governance developments in Chinese higher education compare to the developments in other countries? Stimulating the strategic development of a higher education system where governance responsibilities are split between central and regional authorities can be said to resemble the situation in other federal higher education systems around the world, e.g., Australia, Canada, Germany and the USA. However, a difference - at least so far - is that the Chinese regional authorities have not so much autonomy that they can formally their own regional policy agenda in higher education. However, given the rapid economic development of some regions in China, one 
could expect that some of these have ambitions of selecting and supporting universities aimed at competing with those that currently are centrally affiliated. Here, we can point to the institutional argument that funding creates capabilities for acting (Olsen 2007, 27). The more the authorities of certain Chinese regions can use their economic resources for investments in their universities, the more one could expect these universities to be also formally driven towards "world-class" status. The more such a scenario becomes reality, the more it will undermine the current central Chinese policy agenda with respect to creating a balance between excellence and diversity. This would be in line with experiences in other federal higher education systems: the more federal systems drift away from a clear division of authority and responsibilities between the federal and regional level, the more public authorities at all relevant levels run the danger of creating new complexities related to their own policy priorities.

Funding information Open Access funding provided by Oslo University \& Oslo University Hospital. This work was supported by the China Scholarship Council grant (201706270064).

Open Access This article is licensed under a Creative Commons Attribution 4.0 International License, which permits use, sharing, adaptation, distribution and reproduction in any medium or format, as long as you give appropriate credit to the original author(s) and the source, provide a link to the Creative Commons licence, and indicate if changes were made. The images or other third party material in this article are included in the article's Creative Commons licence, unless indicated otherwise in a credit line to the material. If material is not included in the article's Creative Commons licence and your intended use is not permitted by statutory regulation or exceeds the permitted use, you will need to obtain permission directly from the copyright holder. To view a copy of this licence, visit http://creativecommons.org/licenses/by/4.0/.

\section{References}

Altbach, P. G., \& Salmi, J. (2011). Introduction. In P. G. Altbach \& J. Salmi (Eds.), The road to academic excellence: The making of world-class research universities (pp. 1-9). Washington, DC: World Bank Publications.

Baker, P. (2006). Using corpora in discourse analysis. London: Continuum.

Benner, M., Liu, L., \& Serger, S. S. (2012). Head in the clouds and feet on the ground: Research priority setting in China. Science and Public Policy, 39(2), 258-270.

Bie, D.-R. (2015). University rankings and the construction of world-class universities in China. Journal of Soochow University, 1(1), 54-64.

Capano, G. (2011). Government continues to do its job. A comparative study of governance shifts in the higher education sector. Public Administration, 89(4), 1622-1642.

Castells, M. (2001). Universities as dynamic systems of contradictory functions. In J. Muller, N. Cloete, \& S. Badat (Eds.), Challenges of globalisation: South African debates with Manuel Castells (pp. 206-223). Cape Town: Maskew Miller Longman.

Christensen, T. (2011). University governance reforms: Potential problems of more autonomy? Higher Education, 62(4), 503-517.

Clark, B. R. (1998). Creating entrepreneurial universities: Organizational pathways of transformation. New York: IAU Press.

DiMaggio, P. J., \& Powell, W. W. (1983). The Iron cage revisited: Institutional isomorphism and collective rationality in organizational fields. American Sociological Review, 48(2), 147-160.

Djelic, M. L., \& Sahlin-Andersson, K. (2006). Transnational governance: Institutional dynamics of regulation. Cambridge: Cambridge University Press.

Dong, X., Maassen, P., \& Stensaker, B. (2019). Balancing excellence and diversity in higher education? The role of the Chinese first-level discipline evaluation scheme. Policy Reviews in Higher Education, 3(2), 208-230.

Douglass, J. (2010). Higher education budgets and the global recession: Tracking varied national responses and their consequences. UC Berkeley: Center for Studies in Higher Education.

Frank, R. H., \& Cook, P. J. (1996). The winner-take-all society: Why the few at the top get so much more than the rest of us. New York: Penguin. 
Gornitzka, A., \& Larsen, I. M. (2004). Towards professionalisation? Restructuring of administrative work force in universities. Higher Education, 47(4), 455-471.

Gornitzka, Å., \& Maassen, P. (2000). Hybrid steering approaches with respect to European higher education. Higher Education Policy, 13(3), 267-285.

Gornitzka, Å., \& Maassen, P. (2014). Dynamics of convergence and divergence. Exploring accounts of higher education policy change. In P. Mattei (Ed.), University adaptation at difficult economic times (pp. 13-30). Oxford: Oxford University Press.

Hazelkorn, E. (2015). Rankings and the reshaping of higher education: The battle for world-class excellence. Basingstoke: Palgrave Macmillan UK.

Howlett, M. (2013). Canadian public policy: Selected studies in process and style. Toronto: University of Toronto Press.

Hu, B.-X. (2017). The gradual model of the construction of key universities in China. Journal of Higher Education, 5(1), 30-35.

Kehm, B. M., \& Stensaker, B. (Eds.). (2009). University rankings, diversity, and the new landscape of higher education (pp. VII-XIX). Rotterdam: Sense Publishers.

Kyvik, S. (2009). The dynamics of change in higher education: Expansion and contraction in an organisational field. Dordrecht: Springer Netherlands.

Luo, X.-H. (2008). Research on higher education fiscal investment policy. Beijing: China Financial and Economic Publishing House.

Maassen, P. (2017). The university's governance paradox. Higher Education Quarterly, 71(3), 290-298.

Maassen, P. (2012). System diversity in European higher education. In M. Kwiek \& A. Kurkiewicz (Eds.), The modernisation of European universities (pp. 79-96). Frankfurt am Main: Peter Lang Verlag.

Maassen, P., Moen, E., \& Stensaker, B. (2011). Reforming higher education in the Netherlands and Norway: The role of the state and national modes of governance. Policy Studies, 32(5), 479-495.

Maassen, P., \& Stensaker, B. (2011). The knowledge triangle, European higher education policy logics and policy implications. Higher Education, 61(6), 757-769.

March, J. G., \& Olsen, J. P. (1989). Rediscovering institutions. The organizational basis of politics. New York: The Free Press.

Marginson, S. (2011). Higher education and public good. Higher Education Quarterly, 65(4), 411-433.

Morris, H. (2011). Rankings and the reshaping of higher education: The battle for world class excellence. Studies in Higher Education, 36(6), 741-742.

National Bureau of Statistics of China. (2017). Annual data. http://data.stats.gov.cn/easyquery.htm?cn=C01. Accessed 13 Jan 2018.

Olsen, J. P. (2007). The institutional dynamics of the European University. In P. Maassen \& J. P. Olsen (Eds.), University dynamics and European integration (pp. 25-55). Dordrecht: Springer.

Pusser, B., \& Marginson, S. (2013). University rankings in critical perspective. The Journal of Higher Education, 84(4), 544-568.

Ramirez, F. O., \& Christensen, T. (2013). The formalization of the university: Rules, roots, and routes. Higher Education, 65(6), 695-708.

Riesman, D. (1958). Constraint and variety in American education. New York: Doubleday Anchor.

Salmi, J. (2009). The growing accountability agenda in tertiary education: Progress or mixed blessing? Washington, DC: World Bank.

Stensaker, B., Lee, J., Rhoades, G., Ghosh, S., Castiello, S., Vance, H., Calikoglu, A., Kramer, V., Liu, S., O'Toole, L., Pavluytkin, I., Peel, C., \& Sayed, M. (2018). Stratified University strategies: The shaping of institutional legitimacy in a global perspective. The Journal of Higher Education, 90(4), 539-562.

Tuchman, G. (2009). Wannabe U: Inside the corporate university. Chicago: The University of Chicago Press.

van Vught, F., \& Westerheijden, D. F. (2012). Multidimensional ranking: A new transparency tool for higher education and research. Higher Education Management and Policy, 22(3), 1-26.

Ying, Q., Fan, Y., Luo, D., \& Christensen, T. (2017). Resources allocation in Chinese universities: Hierarchy, academic excellence, or both? Oxford Review of Education, 43(6), 659-676.

Yudkevich, M., Altbach, P. G., \& Rumbley, L. E. (2016). The global academic rankings game: Changing institutional policy, practice, and academic life. New York: Routledge.

Zheng, W., \& Cheng, W. (2012). The multi-dimensional characteristics of Chinese higher education: Chinese model exploration. Educational Research, 7(1), 71-76.

Zhou, C., \& Peng, X.-M. (2008). The entrepreneurial university in China: Nonlinear paths. Science and Public Policy, 35(9), 637-646.

Publisher's note Springer Nature remains neutral with regard to jurisdictional claims in published maps and institutional affiliations. 